\title{
10 ANOS DA REVISTA PERSPECTIVAS EM GESTÃO \& CONHECIMENTO
}

Parece que foi ontem que compartilhávamos com a comunidade científica a criação da revista Perspectivas em Gestão \& Conhecimento (PG\&C) que vinha para somar aos inúmeros periódicos científicos das áreas da Administração, Ciência da Informação e outras muitas, porém com ênfase nos múltiplos olhares que perpassam a intercessão entre gestão e conhecimento sob víeis transdisciplinar. A trajetória de criação, bem como a repercussão disso estão registradas no Editorial do volume 1, número 1 de janeiro a junho de 2011.

Parece que foi ontem, também, precisamente em 2015, que fazíamos alusão aos cinco anos de existência da PG\&C. No Editorial do volume 5, número 1 de janeiro a junho de 2015 expomos os desafios da criação da revista e fizemos um balanço dos seus cinco anos de vida descrevendo o quantitativo de edições publicadas rigorosamente no âmbito da sua periodicidade, bem como reconhecendo a confiança dos muitos autores nacionais e internacionais que escolheram a PG\&C para veicular a sua produção intelectual. Para além disso, reconhecemos o imprescindível e voluntário trabalho de avaliação realizado pelos pareceristas também nacionais e internacionais comprometidos com a qualidade do que a PG\&C publica. Nossa gratidão ao tempo e expertise dedicados ao trabalho de avaliação.

Agora, em 2020, celebramos neste Editorial, com muita alegria e satisfação intelectual, os 10 anos de existência da PG\&C! Celebramos os 10 anos de uma trajetória de desafios, evolução, experiências, conquistas, parcerias e o mais importante: você (leitor, autor, parecerista, membro do Conselho Consultivo) razão da criação e do percurso da PG\&C!

Sabemos que a humanidade está vivendo uma situação de enfrentamento à Pandemia da COVID-19 que vem reverberando em muitos aspectos, mas é fato que a Ciência e os seus canais de comunicação científica, inclusive os periódicos científicos, precisam persistir em sua missão de divulgar o conhecimento científico entre os pesquisadores e o público em geral. Não se pode ignorar a Ciência e o seu papel, pois não há solução fora dela.

Com a PG\&C seguimos firmes no compromisso de contribuir com a Ciência e com as discussões que circundam o foco e escopo da revista no contexto da gestão e do conhecimento de modo inter/pluri/multi/transdisciplinares, discussões estas que representam contribuição para a construção e desenvolvimento de novos conhecimentos teóricos e práticos. Por tudo isso, que venham muitos mais anos a celebrar!

Assim, colocamos à sua disposição o primeiro número do volume 10 da PG\&C, que engloba dois Artigos de Revisão, seis Relatos de Pesquisa e um Relato de Experiência. Para além disso, constam da referida edição este Editorial e o Expediente.

Como últimas palavras, desejamos a todos e a todas uma produtiva leitura! Aproveitamos para reforçar a recomendação em tempo de COVID-19: Se puder, fica em casa! Cuide de si e dos seus!

João Pessoa, Paraíba, Brasil, 27 de Abril de 2020.

Os Editores

Luciana Ferreira da Costa e Jorge de Oliveira Gomes

https://twitter.com/revistapgecufpb

Perspectivas em Gestão \& Conhecimento, João Pessoa, v. 10, n. 1, p. 1, jan./jun. 2020. DOI: http://dx.doi.org/10.21714/2236-417X2020v10n1p1

http://periodicos.ufpb.br/ojs2/index.php/pgc. ISSN: 2236-417X. Publicação sob Licença (cc) EY-NC-ND. 